\title{
Bacterial mutagenicity of the three isomeric dicyclopenta-fused pyrenes: the effects of dicyclopenta topology
}

\author{
María José Otero-Lobato ${ }^{a}$, Leonardus W. Jenneskens ${ }^{\mathrm{a}, *}$, Willem Seinen ${ }^{\mathrm{b}, *, 1}$ \\ ${ }^{a}$ Department of Physical Organic Chemistry, Debye Institute, Utrecht University, Padualaan 8, 3584 CH Utrecht, The Netherlands \\ ${ }^{\mathrm{b}}$ Department of Toxicology, Institute for Risk Assessment Science IRAS, Utrecht University, \\ P.O. Box 80176, 3508 TD Utrecht, The Netherlands
}

Received 14 October 2003; received in revised form 22 December 2003; accepted 12 January 2004

\begin{abstract}
Cyclopenta[ $[c d]$ pyrene (1) and its congeners dicyclopenta[ $c d, m n]$ - (2), dicyclopenta[ $[c d, f g]$ - (3), dicyclopenta[ $[c d, j k]$ pyrene (4), which were all identified as constituents of combustion exhausts, as well as their partially hydrogenated derivatives 3,4-dihydrocyclopenta[cd]- (5), 1,2,4,5-tetrahydrodicyclopenta[cd,mn]- (6), 5,6,7,8-tetrahydrodicyclopenta[cd,fg]- (7) and 1,2,6,7-tetrahydrodicyclopenta[cd,jk]pyrene $\mathbf{( 8 )}$, were assayed for mutagenicity in the Salmonella typhimurium strain TA98 using different concentrations of microsomal protein in the metabolic activation system (S9-mix, with S9-fraction from liver of Aroclor-1254-treated rats: 2, 4 and 10\% (v/v), respectively). Whereas a positive mutagenic response is found for 1-4 in the presence of S9-mix, 5-8 exert no mutagenicity either with or without S9-mix. Since for 1-4 the highest response is observed with S9-mix 2\% (v/v) instead of the standard 4\% (v/v), a one-step activation pathway, i.e. epoxidation of the five-membered ring olefinic bonds, appears to be operational. Surprisingly, $\mathbf{3}$ and, to a lesser extent, 2 (11.7 versus 4.2 His revertants/nmol) also give a positive response in the absence of S9-mix. Hence, $\mathbf{2}$ and $\mathbf{3}$ are expected to contribute to the direct-acting mutagenicity of the non-polar fraction of combustion exhausts. Presumably for the direct-acting mutagenicity one-electron transfer processes play a role in bioactivation. The experimental observations are supported by semi-empirical AM1 calculations on the possible ultimate metabolites, i.e. mono-epoxides (2a-4a), cis-di-epoxides $(\mathbf{2 b}-\mathbf{4 b})$ and trans-di-epoxides $(\mathbf{2} \mathbf{c}-\mathbf{4 c})$ and the related mono-hydroxy carbocations $(\mathbf{2 d}-\mathbf{4 d}$ and $\mathbf{2 e}-\mathbf{4 e})$, and the radical anions $\mathbf{1}^{\mathbf{\bullet}}-\mathbf{4}^{\mathbf{\bullet}}$.
\end{abstract}

(C) 2004 Elsevier B.V. All rights reserved.

Keywords: Bacterial mutagenicity; Non-alternant cyclopenta-fused PAH; Salmonella typhimurium TA98; Semi-empirical AM1 calculations

\section{Introduction}

The non-alternant cyclopenta-fused polycyclic aromatic hydrocarbons (CP-PAHs) constitute a unique sub-class of PAHs that possess at least one unsatu-

\footnotetext{
* Corresponding authors. Tel.: +31-302533128; fax: $+31-302534533$.

E-mail addresses: jennesk@chem.uu.nl (L.W. Jenneskens), w.seinen@iras.uu.nl (W. Seinen).

1 Tel.: +31-302535336; fax: +31-302535077.
}

rated five-membered ring moiety annelated to a PAH core. CP-PAHs are widespread in our environment since they are generated during incomplete combustion processes [1,2]. Although most CP-PAHs lack a 'bay-region', viz. the frequently proposed structural feature required for PAH mutagenic activation, several CP-PAHs possess high (bacterial) mutagenic activity [3-5]. More recently, CP-PAHs were put forward as prime contributors to the total mutagenic activity of the non-polar fraction of combustion exhausts $[6,7]$. A documented example is cyclopenta[cd]pyrene $(\mathbf{1}$, 


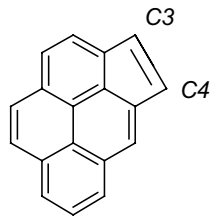

1

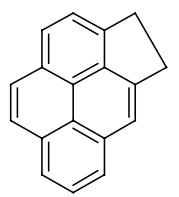

5

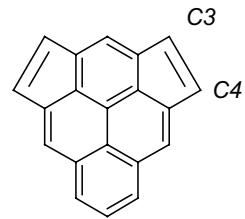

2

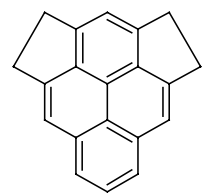

6<smiles></smiles>

3



7<smiles></smiles>

4

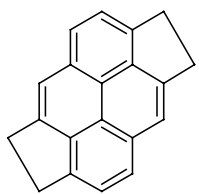

8

Fig. 1. Compounds 1-8 that were assayed for mutagenicity [26].

Fig. 1) [8]. However, despite its high activity, 1 cannot account for the total mutagenic activity of the non-polar fractions. Consequently, the identification and characterisation of other potentially mutagenic $\mathrm{CP}-\mathrm{PAHs}$ present in the non-polar fraction is a topical research issue.

Interesting candidates are the three isomeric dicyclopenta-fused pyrenes, i.e. dicyclopenta[ $[c d, m n]-(\mathbf{2})$, dicyclopenta $[c d, f g]-(\mathbf{3})$ and dicyclopenta $[c d, j k]$ pyrene (4, Fig. 1), which after their unequivocal synthesis $[9,10]$ were identified as constituents of the non-polar fraction of combustion exhausts $[11,12]$. Hence, the availability of pure 2-4 now enables the assessment of their mutagenic response, which can be compared with that of 1 [3]. It is noteworthy that $\mathbf{2 - 4}$ were further suggested as by-products in the thermal treatment of pyrene-contaminated soil [13-15].

Cyclopenta $[c d]$ pyrene (1) has been extensively studied and possesses a marked mutagenic response dependent on metabolism both in bacterial mutagenicity assays [3] and in mammalian in vitro assays [16]. Furthermore, 1 has both tumour-initiating [17] and moderate carcinogenic potential [18]. In the case of $\mathbf{1}$, epoxidation of the five-membered ring olefinic bond (CP-epoxide) $[19,20]$ is postulated as the primary metabolic pathway for its bioactivation by cytochrome P450 (cf. Fig. 7). Subsequent ring opening of the epoxide generates a stable hydroxy carbocation, which may then react with DNA (adduct formation) [21]. This mechanism was substantiated by the isolation of trans-3,4-dihydroxy-3,4-dihydrocyclopenta[ $c d]$ pyrene as the major metabolite derived from $\mathbf{1}$ by liver microsomes [19] as well as the in vitro formation of DNA and epoxide adducts [22-24].

Here, we report the mutagenic response of the novel dicyclopenta-fused pyrene congeners 2-4 in the Salmonella typhimurium strain TA98 Ames assay both with and without exogenous metabolic activation mixture (S9-mix, with Aroclor-1254 rat liver S9-fraction and co-factors). The strain TA98 allows the detection of frameshift mutagens, and has been extensively employed for screening of the mutagenic potency of PAH as recommended in the protocol by Ames and coworkers [25,26].

\section{Materials and methods}

\subsection{Instrumentation}

To gain insight in the reduction potentials of CP-PAHs 1-4 cyclic voltammetry (CV) measurements were performed using a EG\&G Potentiostat/Galvanostat Model $263 \mathrm{~A}$ and freshly distilled (from $\left.\mathrm{CaH}_{2}\right)$ acetonitrile $\left(\mathrm{CH}_{3} \mathrm{CN}\right.$; CAS no. 75-05-8), containing $\quad 0.1 \mathrm{M}$ tetrabutylammonium hexafluorophosphate $\left(\mathrm{Bu}_{4} \mathrm{~N}^{+} \mathrm{PF}_{6}{ }^{-}\right.$; $\mathrm{CAS}$ no. 3109-63-5) as supporting electrolyte at scan rates of 50 and $100 \mathrm{mV} \mathrm{s}^{-1}$ (potential window: -2.5 to $+3 \mathrm{~V}$ ). Redox potentials were determined relative to an $\mathrm{Ag} / \mathrm{AgNO}_{3}$ reference electrode $\left(0.1 \mathrm{M}\right.$ in $\left.\mathrm{CH}_{3} \mathrm{CN}\right)$ and were referenced to the standard calomel electrode (SCE) by 
measuring the oxidation potential of the redox couple $\mathrm{FeCp}_{2} / \mathrm{FeCp}_{2}{ }^{\bullet+}$ (ferrocene/ferrocinium: $0.31 \mathrm{~V}$ versus $\mathrm{SCE}$ ).

\subsection{Chemicals}

Benzo $[a]$ pyrene $(\mathrm{B}[a] \mathrm{P} ; 98.8 \%$, CAS no. 50-32-8) and 1-nitropyrene (1-NP; 99\%, CAS no. 5522-43-0) were purchased from Sigma-Aldrich and used without further purification. Cyclopenta[cd]- (1; CAS no. 27208-37-3), dicyclopenta[cd,mn]- (2; CAS no. 96915-04-7), dicyclopenta[ $c d, f g]$ - (3; CAS no. 173678-72-3) and dicyclopenta[ $c d, j k]$ pyrene (4; CAS no. 98791-43-6) were synthesised and purified as previously reported $[9,10]$. The related partially hydrogenated derivatives 3,4-dihydrocyclopenta[ $c d]$ - (5; CAS no. 25732-74-5), 1,2,4,5-tetrahydrodicyclopenta[cd,mn]- (6; CAS no. 173678-83-6), 5,6,7,8-tetrahydrodicyclopenta[cd,fg]- (7; CAS no. 173678-82-5) and 1,2,6,7-tetrahydrodicyclopenta[cd,jk]pyrene $(\mathbf{8}$; CAS no. 98791-45-8) were prepared by catalytic hydrogenation ( $\left.\mathrm{Pd} / \mathrm{C} 2 \mathrm{mg}, \mathrm{P} / \mathrm{H}_{2} 1 \mathrm{~atm}\right)$ of 1-4 (20 $\mathrm{mg}$ in $15 \mathrm{ml}$ dry THF), respectively, as previously reported [9]. Capillary GC, HPLC, GC-MS, and ${ }^{1} \mathrm{H}$ and ${ }^{13} \mathrm{C}$ NMR showed that in all cases purity was at least $>98.9 \%$. Caution: CP-PAH must be handled according to NIH guidelines for carcinogens.

Dimethyl sulfoxide (DMSO; 99.9\%, CAS no. 67-68-5) was purchased from Aldrich and NADP monosodium salt (98\%, CAS no. 1184-16-3) and D-glucose-6-phosphate anhydrous (G-6-P; 99\%, CAS no. 56-73-5) from Sigma.

\subsection{Mutagenicity assays}

Mutagenicity was assessed using the S. typhimurium histidine (His) auxotrophic strain TA98 following the protocol outlined by Ames and coworkers $[25,26]$ either in the absence or in the presence of a metabolic activation system (S9-mix). The strain TA98 allows the detection of frameshift mutagens, and has been extensively employed for screening of PAH as recommended in the protocol by Ames and coworkers $[25,26]$. The use of a single strain is sufficient to demonstrate a mutagenic response [27].

The S9-mix consists of rat liver microsome preparations (S9-fraction) and the NADPH-generating co-factors (final concentrations: $\mathrm{KCl}, 33 \mathrm{mM} ; \mathrm{MgCl}_{2}$, $8 \mathrm{mM}$; G-6-P, $5 \mathrm{mM}$; NADP, $4 \mathrm{mM}$; $\mathrm{NaH}_{2} \mathrm{PO}_{4}(\mathrm{pH}$ 7.4), $100 \mathrm{mM}$ ). The $\mathrm{S} 9$-fraction was obtained from Aroclor-1254 treated-male rats (U:WU(CPB) Wistar), and the total protein content $(29.15 \mathrm{mg} / \mathrm{ml})$ was determined using the Lowry et al.'s method [28]. The EROD method [29] was used to determine the activity of the cytochrome P450 isoenzyme P450-1A in the $\mathrm{S} 9$-fraction $(51.58 \mathrm{pmol} / \mathrm{ml} \mathrm{min} \mathrm{mg}$ protein).

Compounds 1-8 were dissolved in DMSO $(500 \mu \mathrm{g} / \mathrm{ml})$ and tested at eight different concentrations ranging from 0 to $20 \mu \mathrm{g}$ per plate in a constant volume of DMSO (100 $\mu$ l per plate). Compound 2 was tested in the range from 0 to $8 \mu \mathrm{g}$ per plate without S9-mix, and 0 to $12 \mathrm{mg}$ per plate with S9-mix. Note that in the assay with S9-mix 4\% (v/v) the His revertants could not be counted above $8 \mu \mathrm{g}$ per plate (see Section 3). All assays were performed in triplicate in the absence $(-\mathrm{S} 9)$ and in the presence of a metabolic activation mixture (S9-mix) at three microsomal protein levels (S9-mix: $2 \%(\mathrm{v} / \mathrm{v})$, i.e. $0.29 \mathrm{mg}$ protein per plate; $4 \%(\mathrm{v} / \mathrm{v})$, i.e. $0.58 \mathrm{mg}$ protein per plate; $10 \%(\mathrm{v} / \mathrm{v})$, i.e. $1.45 \mathrm{mg}$ protein per plate) in at least two independent experiments. Spontaneous revertants for TA98 were scored $(-\mathrm{S} 9,16 \pm 2 ;+\mathrm{S} 9$, $31 \pm 7$ ), as well as positive controls, i.e. $1-\mathrm{NP}, 5.0 \mu \mathrm{g}$ per plate $(-\mathrm{S} 9,>1000)$ and $\mathrm{B}[a] \mathrm{P}, 1.0 \mu \mathrm{g}$ per plate (for example, + S9-mix $4 \%(\mathrm{v} / \mathrm{v}), 158.5 \pm 10)$. The positive controls are well-established mutagens in the TA98 strain, viz. 1-NP acts as a direct-acting mutagen [30] and $\mathrm{B}[a] \mathrm{P}$ as a metabolic-dependent mutagen [31]. DMSO was used as negative control $(-\mathrm{S} 9$, $29 \pm 7 ;+S 9,38 \pm 9$ ). The plates were incubated at $37^{\circ} \mathrm{C}$ for $48 \mathrm{~h}$ and the His revertant colonies counted manually. Each dose was tested in triplicate in at least two independent experiments. The results obtained are presented as dose-response curves and are expressed as mean values of His revertant colonies per dose of test compound without correction for spontaneous reversion; the standard deviation is expressed in error bars (see also Appendix A).

The following criteria taken from the literature $[32,33]$ were used to establish a mutagenic response: (i) three-fold increase in the number of revertants in treated plates as compared to the negative control; (ii) ascending dose-response behaviour and (iii) replication of results in at least two independent experiments. The three-fold increase criterion alone is considered 
Table 1

Specific mutagenic activity ${ }^{\mathrm{a}}$, expressed in His revertants/nmol, of cyclopenta[cd]- (1), dicyclopenta $[c d, m n]-(\mathbf{2})$, dicyclopenta[cd,fg]- (3) and dicyclopenta $[c d, j k]$ pyrene (4) and their partially hydrogenated derivatives 5-8 in S. typhimurium TA98 strain without (-S9-mix) and with metabolic activation system (+S9-mix) at three different concentration microsome protein levels: $2 \%(\mathrm{v} / \mathrm{v}), 0.29 \mathrm{mg}$ per plate; $4 \%$ $(\mathrm{v} / \mathrm{v}), 0.58 \mathrm{mg}$ per plate; $10 \%(\mathrm{v} / \mathrm{v}), 1.45 \mathrm{mg}$ per plate

\begin{tabular}{lcccc}
\hline Compound & TA98 (-S9-mix) & TA98 (+S9-mix 2\% (v/v)) & TA98 (+S9-mix 4\% (v/v)) & TA98 (+S9-mix 10\% (v/v)) \\
\hline $\mathbf{1}$ & $\sim 0.5$ & 63.5 & 27.5 & 28.6 \\
$\mathbf{2}$ & 4.2 & 163.3 & 98.4 & 41.8 \\
$\mathbf{3}$ & 11.7 & 48.0 & 23.2 & 38.5 \\
$\mathbf{4}$ & 1.2 & 82.0 & 14.7 & 33.3 \\
$\mathbf{5}$ & $\sim 0.1$ & - & $\sim 0.3$ & - \\
$\mathbf{6}$ & $\sim 0.1$ & - & $\sim 0.2$ & - \\
$\mathbf{7}$ & $\sim 0.4$ & - & $\sim 0.2$ & - \\
$\mathbf{8}$ & $\sim 0.1$ & $-\mathrm{b}$ & 30.4 & $-\mathrm{b}$ \\
$\mathrm{B}[a] \mathrm{P}$ & $\sim 0.1$ & $-\mathrm{b}$ & \\
\hline
\end{tabular}

${ }^{\text {a }}$ His revertants/nmol was calculated by least-squares regression from the ascending linear portion of the dose-response curve (Figs. 2-6). The standard deviation (shown in Figs. 2-5 as error bars) is included in the calculation of the slopes. The mean number of His revertants and the standard deviation from each tested dose, as well as the correlation coefficients $\left(r^{2}\right)$ from the linear regression, are shown in Appendix A.

${ }^{\mathrm{b}}$ In another study in which $S$. typhimurium TA98 was used, the specific mutagenic activity of $\mathrm{B}[a] \mathrm{P}$ was determined at different microsomal protein content in the S9-mix [31]. It was found to increase when more protein content in the S9-mix was used.

to be not sufficient to conclude if a compound is a mutagen or not [34].

The number of His revertants induced per nanomole of test compound, i.e. the specific mutagenic activity (Table 1), was also calculated by least-squares regression from the ascending linear portion of the dose-response curve (Figs. 2-6). All actual data for each tested dose (mean value from six plates \pm standard deviation) and the correlation coefficients are reported in Appendix A.

\subsection{Computations}

To obtain estimates of the heats of formation $\left(\Delta H_{\mathrm{f}}^{\circ}\right.$ in $\mathrm{kcal} / \mathrm{mol}$ ) of the compounds and intermediates shown in Fig. 7 as well as the electron affinities (EA,

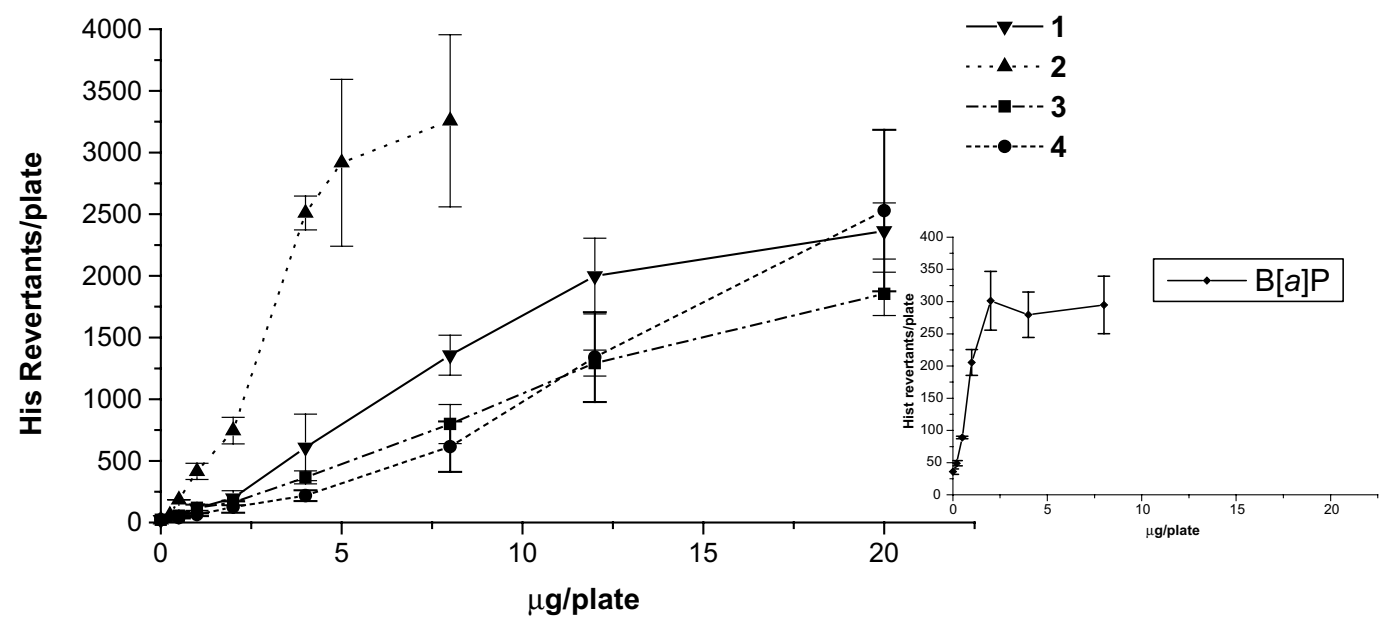

Fig. 2. Dose-response curves of mutagenicity of cyclopenta $[c d]-(\mathbf{1})(\boldsymbol{\nabla})$, dicyclopenta[ $[c d, m n]-(\mathbf{2})$ (above $8 \mu \mathrm{g}$ per plate of $\mathbf{2}$ the number of His revertant colonies markedly increased hampering their precise manual counting. No toxicity is observed) $(\mathbf{\Delta})$, dicyclopenta[ $[c d, f g]-$ (3) (ם) and dicyclopenta[ $[c d, j k]$ pyrene (4) (O). Inset: dose-response curve for B $[a] \mathrm{P}$. The standard protocol [26] was followed using the S. typhimurium tester strain TA98 with metabolic activation $(+\mathrm{S} 9-\mathrm{mix} 4 \%(\mathrm{v} / \mathrm{v}))$. 


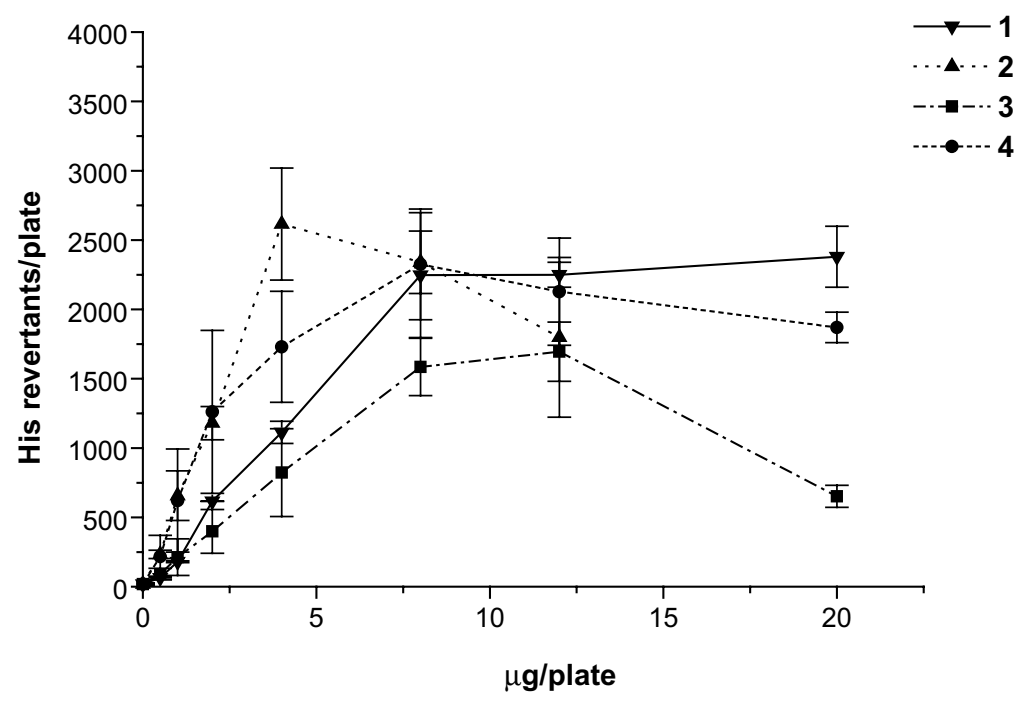

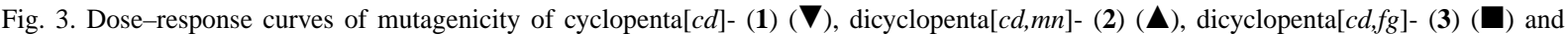
dicyclopenta[cd,jk]pyrene (4) (O). The standard protocol [26] was followed using the $S$. typhimurium tester strain TA98 with metabolic activation $(+\mathrm{S} 9-\operatorname{mix} 2 \%(\mathrm{v} / \mathrm{v}))$.

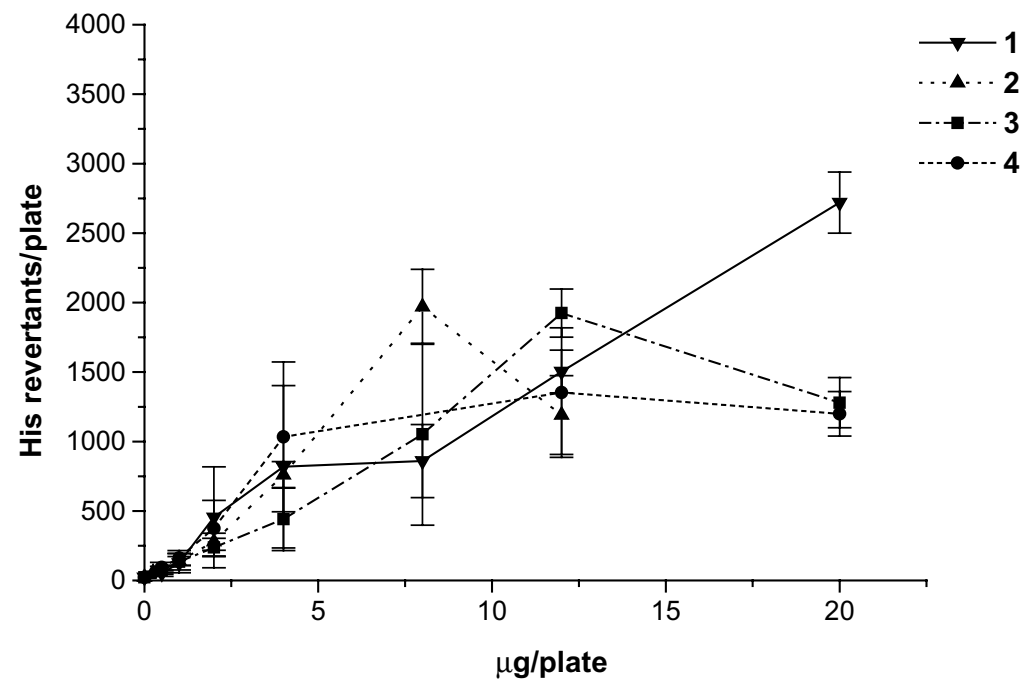

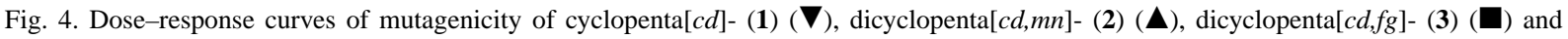
dicyclopenta[cd,jk]pyrene (4) (O). The standard protocol [26] was followed using the $S$. typhimurium tester strain TA98 with metabolic activation $(+\mathrm{S} 9-\operatorname{mix} 10 \%(\mathrm{v} / \mathrm{v}))$.

Table 3) of CP-PAHs 1-4, i.e. for the conversion of 1-4 into their radical anions $\mathbf{1}^{\bullet-}-\mathbf{4}^{\bullet-}$, semi-empirical restricted Hartree-Fock (RHF) AM1 calculations (RHF/AM1) were performed using the MOPAC 7.0 program until GNORM $<0.05$ [35]. EA values are calculated according to $\mathrm{EA}=-\left(\Delta H_{\mathrm{f}}^{\circ}\left(\mathbf{1}^{\bullet-}-\mathbf{4}^{\bullet-}\right)-\right.$
$\left(\Delta H_{\mathrm{f}}^{\circ}(\mathbf{1}-\mathbf{4})\right)$ in which the $\Delta H_{\mathrm{f}}^{\circ}$ values represent the calculated heats of formation. The structures of the ground-state (closed-shell) molecules 1-4 and their (open-shell) radical anions $\mathbf{1}^{\bullet-}-\mathbf{4}^{\bullet-}$ were optimised without imposing any geometry constraints. For the open-shell radical anions the structures were ini- 


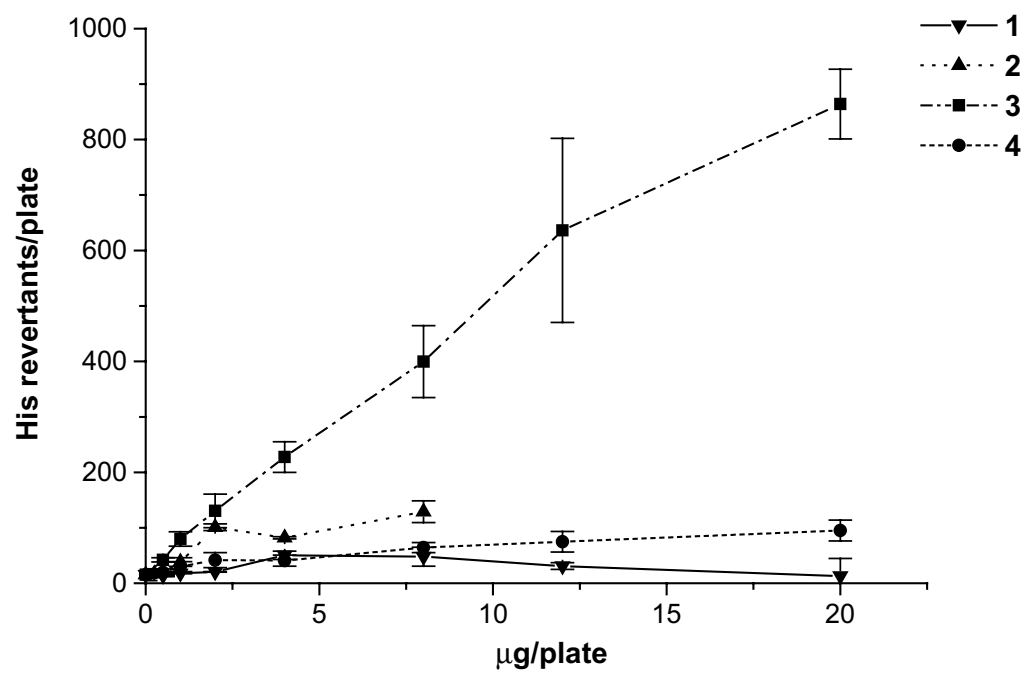

Fig. 5. Dose-response curves of mutagenicity of cyclopenta[cd]- (1) $(\boldsymbol{\nabla})$, dicyclopenta[cd,mn]- (2) $(\mathbf{\Delta})$, dicyclopenta[cd,fg]- $(\mathbf{3})(\boldsymbol{\square})$ and dicyclopenta[cd,jk]pyrene (4) (O). The standard protocol [26] was followed using the S. typhimurium tester strain TA98 without metabolic activation (-S9-mix); note the different scale for His revertants per plate (cf. Figs. 2-4).

tially optimised using the unrestricted Hartree-Fock AM1 method (UHF/AM1) followed by a final re-optimisation using RHF/AM1 and the half-electron approach until GNORM <0.05 [35]. All computed minima were characterised by Hessian calculations; in all cases no imaginary frequencies were found.

\section{Results}

The bacterial mutagenic response of cyclopenta[cd](1), dicyclopenta[cd,mn]- (2), dicyclopenta[cd,fg](3) and dicyclopenta[cd,jk]pyrene (4) and their corresponding partially hydrogenated congeners 5-8 (Fig. 1) were assessed in the S. typhimurium TA98 His reverse mutation assay either in the absence $(-\mathrm{S} 9)$ or in the presence of different concentrations of S9-fraction in the S9-mix. The dose-response curves for both the direct-acting (-S9) and metabolic activation-dependent mutagenicity $(+\mathrm{S} 9-\mathrm{mix})$ are shown in Figs. $2-5$ and the specific mutagenic activity of 1-8 is reported in Table 1 (see also Appendix A).

Under standard metabolic activation conditions (S9-mix 4\% (v/v)) the CP-PAHs 1-4 all show a positive mutagenic response. Whereas $\mathbf{1}$ shows a specific mutagenic activity of 27.5 His revertants/nmol and $\mathbf{3}$ and $\mathbf{4}$ a specific mutagenic activity of 23.2 and 14.7
His revertants/nmol, 2 exhibits the highest response (98.4 His revertants/nmol, Table 1). Under these conditions none of the compounds were toxic: no decrease of His revertants was found in the whole concentration range. In comparison, the $\mathrm{B}[a] \mathrm{P}$ induces 30.4 His revertants/nmol under similar conditions (Fig. 2), which is in line with reported data [31]. In contrast to the behaviour of $\mathbf{1 - 4}$, the partially hydrogenated derivatives 5-8 do not show any positive mutagenic activity under these conditions (Table 1).

Since it was established for cyclopenta[cd]pyrene (1) [3] and, later, confirmed for other CP-PAH [4,36] that maximal bacterial mutagenicity is exerted when less microsomal protein is used in the S9-mix than the standard $4 \%(\mathrm{v} / \mathrm{v})$, we were prompted to study the effect of protein content on the mutagenic response of 2-4. Two additional concentrations (S9-mix, 2 and $10 \%(\mathrm{v} / \mathrm{v}))$ of microsomal protein in the S9-mix were used.

With S9-mix 2\% (v/v), 2 exerts the highest mutagenic response (specific mutagenic activity of 163.3 His revertants/nmol), followed by 4 ( 82.0 His revertants/nmol), 1 (63.5 His revertants/nmol) and 3 (48.0 His revertants/nmol) (Fig. 3 and Table 1). With the exception of $\mathbf{1}$, a decrease in the number of His revertants after maximum mutagenic induction is observed. This is caused by cell toxicity. Nevertheless, the presence 

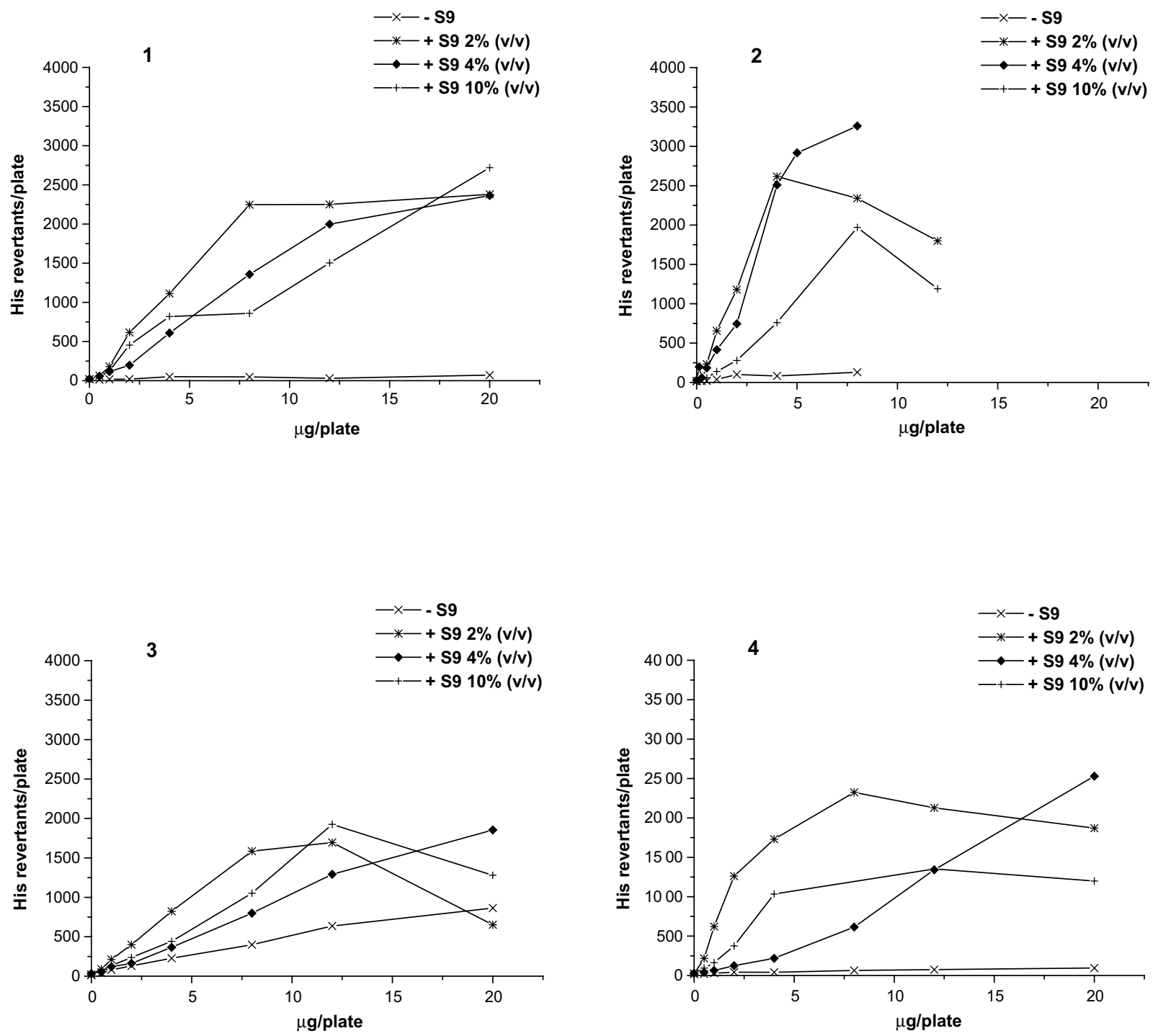

Fig. 6. Dose-mutagenicity response curves at different microsomal content of cyclopenta[cd]- (1), dicyclopenta[cd,mn]- (2), dicyclopenta[ $[c d, f g]-(3)$ and dicyclopenta[ $c d, j k]$ pyrene (4). The standard protocol [26] was followed using the $S$. typhimurium tester strain TA98 without metabolic activation $-\mathrm{S} 9$-mix $(\times)$, with metabolic activation + S9-mix $2 \%(\mathrm{v} / \mathrm{v})(*),+\mathrm{S} 9-\mathrm{mix} 4 \%(\mathrm{v} / \mathrm{v})(\diamond)$ and $+\mathrm{S} 9$-mix $10 \%(\mathrm{v} / \mathrm{v})(+)$. The error bars (standard deviation) are not shown.

of less S9-fraction in the S9-mix clearly enhances the bacterial mutagenic activity of 1-4 compared with the experiment with $4 \%(\mathrm{v} / \mathrm{v}) \mathrm{S} 9$-mix.

With S9-mix 10\% (v/v) the mutagenic response of 2 is greatly reduced (41.8 His revertants/nmol) and exhibits toxicity at concentrations higher than $8 \mu \mathrm{g}$ per plate (Fig. 4). Whereas 1 shows a similar response (28.6 His revertants/nmol), in the case of $\mathbf{3}$ and $\mathbf{4}$ (38.5 and 33.3 His revertants/nmol, respectively) a moderate increase of mutagenic activity is found compared with the experiment with S9-mix 4\% (v/v). Notwithstanding, all compounds are less active than when S9-mix $2 \%(\mathrm{v} / \mathrm{v})$ is employed. Furthermore, whereas $\mathbf{1}$ is not toxic in the whole concentration range, $\mathbf{3}$ and $\mathbf{4}$ show toxicity at concentrations higher than $12 \mu \mathrm{g}$ per plate under these conditions (Fig. 4). 


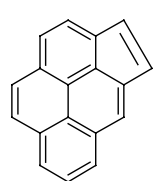

1, $\Delta H_{f}^{\circ} 109.4$

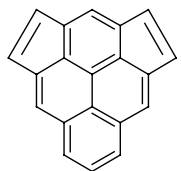

2, $\Delta \mathrm{H}_{\mathrm{f}}^{0} 158.4$

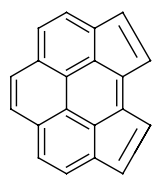

3, $\Delta \mathrm{H}_{\mathrm{f}}^{\mathrm{o}} 152.2$

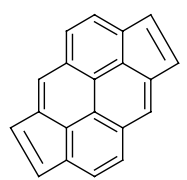

4, $\Delta \mathrm{H}_{\mathrm{f}}{ }^{\mathrm{1}} 154.6$

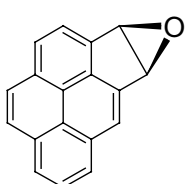

1a, $\Delta \mathrm{H}_{\mathrm{f}}^{\circ} 90.7$

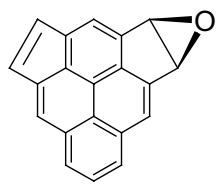

2a, $\Delta \mathrm{H}_{\mathrm{f}}^{\circ} 138.4$

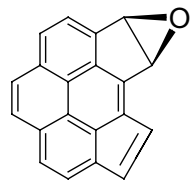

3a, $\Delta \mathrm{H}_{\mathrm{f}}^{0} 133.2$

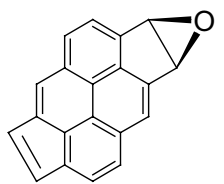

4a, $\Delta \mathrm{H}_{\mathrm{f}}^{\circ} 135.1$

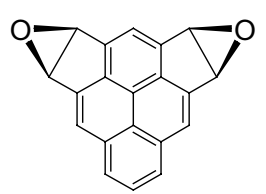

cis-2b, $\Delta \mathrm{H}_{\mathrm{f}}^{0} 118.9$



cis-3b, $\Delta \mathrm{H}_{\mathrm{f}}^{0} 114.9$

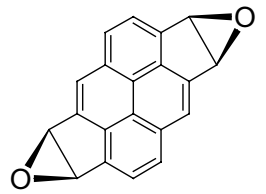

cis- $4 \mathbf{b}, \Delta \mathrm{H}_{\mathrm{f}}^{0} 116.0$
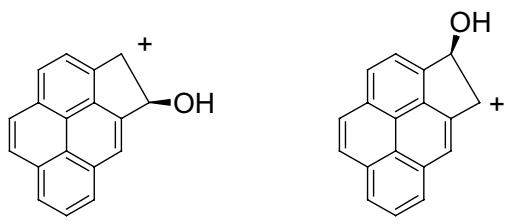

1d, $\Delta \mathrm{H}_{\mathrm{f}}{ }^{\circ} 222.2$

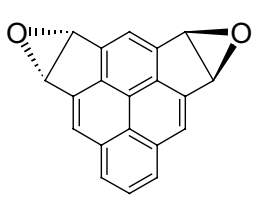

trans-2c, $\Delta \mathrm{H}_{\mathrm{f}}^{0} 118.7$

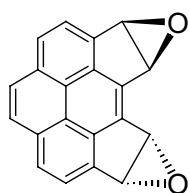

trans-3c, $\Delta \mathrm{H}_{\mathrm{f}}^{0} 114.5$

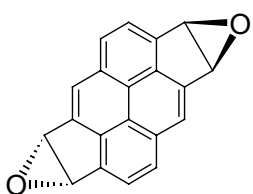

trans $-4 \mathbf{c}, \Delta \mathrm{H}_{\mathrm{f}}^{0} 115$

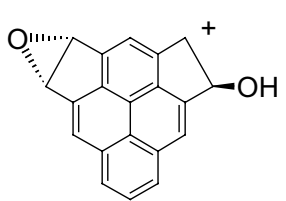

2d, $\Delta \mathrm{H}_{\mathrm{f}}^{\mathrm{o}} 251.5\left(251.6^{\mathrm{a}}\right)$

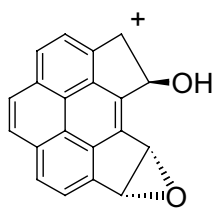

3d, $\Delta \mathrm{H}_{\mathrm{f}}{ }^{0} 249.2\left(250.0^{\mathrm{a}}\right)$



4d, $\Delta \mathrm{H}_{\mathrm{f}}^{\mathrm{o}} 250.8\left(250.9^{\mathrm{a}}\right)$ 1e, $\Delta \mathrm{H}_{\mathrm{f}}^{0} 228.6$



2e, $\Delta \mathrm{H}_{\mathrm{f}}^{\mathrm{o}} 259.4\left(259.6^{\mathrm{a}}\right)$

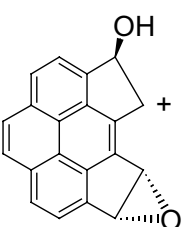

3e, $\Delta \mathrm{H}_{\mathrm{f}}^{\mathrm{o}} 255.6\left(256.5^{\mathrm{a}}\right)$

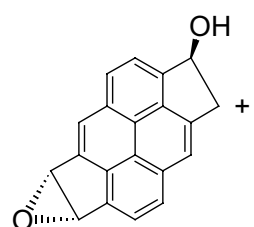

4e, $\Delta \mathrm{H}_{\mathrm{f}}^{\mathrm{o}} 255.7\left(255.8^{\mathrm{a}}\right)$

Fig. 7. AM1 ( $\Delta H_{\mathrm{f}}^{\circ}$ in $\left.\mathrm{kcal} / \mathrm{mol}\right)$ values for $\mathbf{1}-\mathbf{4}$ and their related mono-epoxides $(\mathbf{1 a}-\mathbf{4 a})$, the cis-di-epoxides $(\mathbf{2 b}-\mathbf{4 b})$ and trans-di-epoxides $(\mathbf{2} \mathbf{c}-\mathbf{4 c})$, and the two possible mono-hydroxy carbocations with a formal positive charge at either C3 (1d-4d) or C4 (1e-4e). Note that the mono-hydroxy carbocations $(\mathbf{2 d}-\mathbf{4 d}$ and $\mathbf{2 e - 4 e )}$ derived from the cis-di-epoxides $(\mathbf{2 b}-\mathbf{4 b})$ and trans-di-epoxides $(\mathbf{2} \mathbf{c}-\mathbf{4 c})$, respectively, possess a different stereochemistry. Here, $\mathbf{2 d - 4 d}$ and $\mathbf{2 e - 4 e}$ correspond to the mono-hydroxy carbocations obtained from the trans-di-epoxides $\mathbf{2 c}-\mathbf{4 c}$. The $\left(\Delta H_{\mathrm{f}}^{\circ}\right)$ values between parentheses for $\mathbf{2 d}-\mathbf{4 d}$ and $\mathbf{2 e}-\mathbf{4 e}$ correspond to the mono-hydroxy carbocations derived from the cis-di-epoxides $(\mathbf{2} \mathbf{b}-\mathbf{4 b})$, of which the actual optimised AM1 structures are not shown. 
In Fig. 5, the dose-response curve for mutagenicity without any metabolic activation mixture $(-\mathrm{S} 9)$ is depicted. Whilst $\mathbf{1}$ is totally inactive, compound 4 is marginally mutagenic (1.2 His revertants/nmol). Surprisingly, 2 shows weak activity (4.2 His revertants/nmol) and $\mathbf{3}$ a relatively high mutagenic response (11.7 His revertants/nmol) (Table 1).

\section{Discussion}

\subsection{Ames assays}

CP-PAHs 1-4 exhibit a metabolic activation-dependent positive mutagenic response at all concentrations of microsomal protein (S9-fraction) tested in the exogenous activation mixture (S9-mix). The results show that mutagenic activity of 2-4 like that of 1 [3] increases markedly with the low concentration of S9-fraction in the exogenous S9-mix, viz. S9-mix $2 \%(\mathrm{v} / \mathrm{v})$ (Fig. 6). This dependence of the mutagenic response on the amount of $\mathrm{S} 9$-fraction present in the S9-mix suggests that 1-4 possess similar metabolic activation mechanisms. The low S9-fraction optimum for maximal mutagenic response is proposed to correlate with a one-step metabolic activation pathway, i.e. epoxidation of the five-membered ring olefinic bonds [4]. Other PAHs, such as B[a]P, are known to be activated via vicinal dihydrodiol epoxide forms at the 'bay-region', which is a multi-step activation mechanism. These 'bay-region' PAH exert their maximal mutagenic response with a higher microsomal protein content in the S9-mix [37]. The high activity of CP-PAH at low microsomal protein content (S9-fraction) in the S9-mix appears to be a general characteristic [3,4,31,36]. Apparently, at higher concentrations of S9-fraction detoxification processes become operative in the case of $\mathrm{CP}-\mathrm{PAH}$, which will then reduce their mutagenic activity.

The formation of the epoxides at the externally fused cyclopenta ring is further corroborated by the absence of a mutagenic response found for the partially hydrogenated CP-PAH derivatives 5-8, both in the absence and in the presence of standard S9-mix. Hence in the case of 1-4, the presence of the cyclopenta-fused etheno moiety is mandatory to exert bacterial mutagenicity.

\subsection{Epoxidation of olefinic bonds: AM1 calculations}

Since both semi-empirical [35] and ab initio [38-41] calculations as well as available single X-ray crystal structures $[42,43]$ of CP-PAH show that the externally fused five-membered rings possess (localised) olefinic bonds, it is expected that these bonds will be most susceptible to undergo epoxidation by cytochrome P450 epoxidases present in the S9-mix (Fig. 7).

Thus, the cis-di-epoxide (2b-4b) and trans-di-epoxide derivatives $(\mathbf{2 c - 4 c})$ are the proposed ultimate mutagenic species (Fig. 7). After conversion of an epoxide functionality into a mono-hydroxy carbocation intermediate ( $\mathbf{2 d}-\mathbf{4 d}$, vide infra) by epoxide ring opening, the carbocation may react with DNA (adduct formation) and subsequently cause mutagenicity [44]. To gain insight into the stabilities of 1-4 and their derivatives, i.e. the mono-epoxides (1a-4a), the cis-di-epoxides $(\mathbf{2} \mathbf{b}-\mathbf{4 b})$ and trans-di-epoxides $(\mathbf{2 c}-\mathbf{4 c})$, as well as the possible mono-hydroxy carbocations with a formal positive charge at $\mathrm{C} 3(\mathbf{1 d}-\mathbf{4 d})$ or at $\mathrm{C} 4(\mathbf{1 e - 4 e )}$ (Fig. 7), their heats of formation $\left(\Delta H_{\mathrm{f}}^{\circ}\right.$ in $\left.\mathrm{kcal} / \mathrm{mol}\right)$ were calculated using the semi-empirical AM1 method (Table 2 and Section 2) [35]. Since 2-4 and their corresponding derivatives are constitutional isomers, a comparison of $\Delta H_{\mathrm{f}}^{\circ}$ values of related species will directly reflect their relative stability. The results show that with the exception of the mono-hydroxy carbocations (2e-4e), which formally contain a positive charge at position $\mathrm{C} 4$, the stability order for all related compounds is $\mathbf{3}$ (3a-3d) $>$ 4 (4a-4d) $>\mathbf{2}(\mathbf{2 a}-\mathbf{2 d}$ ) (see Fig. 7). The mono-hydroxy carbocations containing the formal positive charge at position C3 $(\mathbf{1 d}-\mathbf{4 d})$ are found to be more stable than those with a formal positive charge at position $\mathrm{C} 4(\mathbf{1 e}-\mathbf{4 e})$. This is readily explained by the fact that $\mathbf{1 d}-\mathbf{4 d}$ represent analogues of a stabilised benzylic carbocation.

To obtain an estimate of the propensity of 1-4 towards epoxidation of the olefinic bonds the energy differences $(\Delta E$ in $\mathrm{kcal} / \mathrm{mol})$ between the mono-epoxides $(\mathbf{1 a}-\mathbf{4 a})$, the corresponding cis-di-epoxides $(\mathbf{2} \mathbf{b}-\mathbf{4 b})$ and trans-di-epoxides (2c-4c) and 1-4, respectively, were calculated (Table 2). For the mono-CP-epoxides (1a-4a) the $\Delta E$ values are close to half the $\Delta E$ values computed for the related cis-di-epoxides $(\mathbf{2} \mathbf{b}-\mathbf{4} \mathbf{b})$ and the trans-di-epoxides $(\mathbf{2}-\mathbf{c}-\mathbf{c})$. Note that $\mathbf{2 b}-\mathbf{4 b}$ and $\mathbf{2 c}-\mathbf{4 c}$, respectively, possess nearly identical $\Delta H_{\mathrm{f}}^{\circ}$ 
Table 2

Semi-empirical AM1 energy difference $(\Delta E)$ of the corresponding mono-epoxides (1a-4a), the cis-di-epoxides (2b-4b) and trans-di-epoxides (2c-4c), and the two possible mono-hydroxy carbocations (1d-4d and 1e-4e, see Fig. 7)

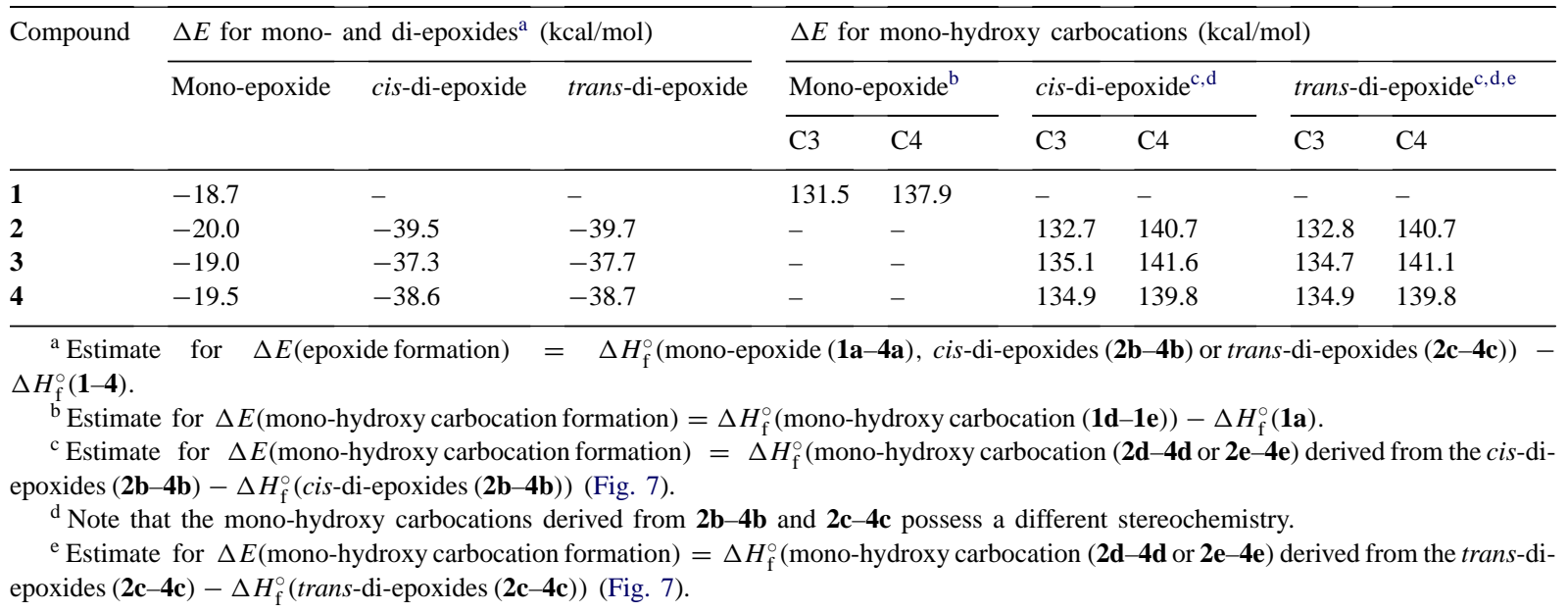

values $\left(\Delta H_{\mathrm{f}}^{\circ}=0.1-0.4 \mathrm{kcal} / \mathrm{mol} ;\right.$ Fig. 7 and Table 2$)$. These results indicate that epoxidation of both olefinic bonds of 2-4 will occur. The AM1 $\Delta E$ values for mono-epoxide (2a-4a) and cis-di-epoxide $(\mathbf{2} \mathbf{b}-\mathbf{4} \mathbf{b})$ and trans-di-epoxide (2c-4c) formation suggest that epoxidation occurs in the order $\mathbf{2}>\mathbf{4}>\mathbf{3}$. This order is also found for the mutagenic response of $\mathbf{2}-\mathbf{4}$ with S9-mix $2 \%(\mathrm{v} / \mathrm{v})$, i.e. the optimal concentration of protein in the exogenous metabolic activation mixture for maximal mutagenic response (Table 1).

\subsection{Direct mutagenicity of $\mathbf{2}$ and $\mathbf{3}$}

As shown in Fig. 5, CP-PAH 2 and especially 3 are found to be direct mutagens (2: ca. 130 His revertants and 3: ca. $400 \mathrm{His}$ revertants per plate at $8 \mu \mathrm{g}$ per plate (see Appendix A)); they exhibit mutagenic activity in the absence of exogenous metabolic activation. In previous work, benz $[k]$ aceanthrylene $(\mathrm{B}[k] \mathrm{AA})$ and benz $[d]$ aceanthrylene $(\mathrm{B}[d] \mathrm{AA})$ were identified as direct-acting mutagens under similar conditions [45] and their positive activity was attributed to the facile (spontaneous) formation of their endo-peroxides. In addition, other aceanthrylene derivatives were found to possess direct mutagenicity in a bacterial forward mutation assay [7]. However, neither the benzaceanthrylenes nor the aceanthrylenes have been identified as constituents of the non-polar fraction of combustion exhausts [8]. Hence, $\mathbf{2}$ and in particular $\mathbf{3}$ represent the first two CP-PAH that were recently unequivocally identified in the non-polar fraction of combustion exhausts [11,12].

The S9-independent bacterial mutagenic activity in the polar fraction of combustion exhausts is primarily accounted for by the presence of nitro-PAH [46], which possess an extremely high mutagenic activity [30]. For instance, for 1-NP a direct-acting specific mutagenicity of 339 revertants/nmol (tester strain TA98) has been reported [47]. In the case of nitro-PAH active metabolites are supposedly obtained by two consecutive one-electron reduction steps followed by the formation of nitroso derivatives that are subsequently further metabolised enzymatically [48]. Hence for nitro-PAH, their first reduction potential $\left(E_{1 / 2}(0 /-1)\right.$ in $\mathrm{V}$ versus $\left.\mathrm{SCE}\right)$, which is directly proportional to their electron affinity $\left(E_{1 / 2}(0 /-1) \propto\right.$ EA), is frequently used as a criterion to explain and predict direct bacterial mutagenic response [49-52].

Using both cyclic voltammetry and calculations we have recently shown that non-alternant CP-PAH containing externally fused five-membered rings possess a markedly enhanced electron affinity, i.e. less negative first electron reduction potentials $\left(E_{1 / 2}(0 /-1)\right.$ in $\mathrm{V}$ versus SCE) [53-55]. CP-PAH 3 possesses the least negative first reduction potential $E_{1 / 2}(0 /-1)$ of $-1.02 \mathrm{~V}\left(E_{1 / 2}(0 /-1\right.$ in $\mathrm{V}$ versus SCE: $1,-1.56 \mathrm{~V} ; \mathbf{2}$, $-1.32 \mathrm{~V} ; \mathbf{4},-1.15 \mathrm{~V}$ (Table 3$)$ ), which is exactly in the range found for some bioactive nitro-PAH exhibit- 
Table 3

First reduction potential $\left(E_{1 / 2}\left(0 /-1\right.\right.$ in V versus SCE) of 1-4 measured using cyclic voltammetry, their $-\varepsilon_{\text {LUMO }}(\mathrm{AM} 1)$ energies and their AM1 EA values ${ }^{\mathrm{a}}$

\begin{tabular}{lllll}
\hline Compound & $E_{1 / 2}(0 /-1)(\mathrm{V}$ versus SCE $)$ & $E(-1 /-2)(\mathrm{V}$ versus SCE $)$ & $-\varepsilon_{\mathrm{LUMO}} \mathrm{b}(\mathrm{eV})$ & $\mathrm{EA}(\mathrm{eV})$ \\
\hline $\mathbf{1}$ & -1.56 & -2.22 & -1.312 & 1.70 \\
$\mathbf{2}$ & -1.32 & -2.06 & -1.540 & 1.90 \\
$\mathbf{3}$ & -1.02 & -1.54 & -1.696 & 2.15 \\
$\mathbf{4}$ & -1.15 & -1.63 & -1.637 & 2.03 \\
\hline
\end{tabular}

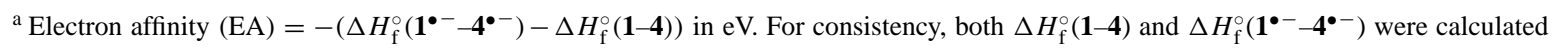
at the RHF/AM1 level of theory $\left(\Delta H_{\mathrm{f}}^{\circ}(\mathbf{1}) 109.4 \mathrm{kcal} / \mathrm{mol}, \Delta H_{\mathrm{f}}^{\circ}(\mathbf{2}) 158.4 \mathrm{kcal} / \mathrm{mol}, \Delta H_{\mathrm{f}}^{\circ}(\mathbf{3}) 152.2 \mathrm{kcal} / \mathrm{mol}\right.$ and $\Delta H_{\mathrm{f}}^{\circ}(\mathbf{4}) 154.6 \mathrm{kcal} / \mathrm{mol}$, and $\Delta H_{\mathrm{f}}^{\circ}\left(\mathbf{1}^{\bullet-}\right) 70.2 \mathrm{kcal} / \mathrm{mol}, \Delta H_{\mathrm{f}}^{\circ}\left(\mathbf{2}^{\bullet-}\right) 114.5 \mathrm{kcal} / \mathrm{mol}, \Delta H_{\mathrm{f}}^{\circ}\left(\mathbf{3}^{\bullet-}\right) 102.6 \mathrm{kcal} / \mathrm{mol}$ and $\Delta H_{\mathrm{f}}^{\circ}\left(\mathbf{4}^{\bullet-}\right) 107.7 \mathrm{kcal} / \mathrm{mol}$; see Section 2$)$.

${ }^{\mathrm{b}}$ RHF/AM1 LUMO energy (in eV) of closed-shell 1-4 following Koopmans theorem [57] $\left(E_{1 / 2}(0 /-1) \propto\right.$ EA $\left.\propto-\varepsilon_{\text {LUMO }}\right)$.

ing direct-acting mutagenic behaviour [49]. In contrast, the $E_{1 / 2}(0 /-1)$ values of $\mathbf{2}$ and $\mathbf{4}$ represent borderline cases. Thus the propensity of $\mathbf{2}-\mathbf{4}$ to undergo one-electron reduction follows the order $3>\mathbf{4}>\mathbf{2}$. A similar order is found for their second one-electron reduction potential $\left(E_{1 / 2}(-1 /-2): \mathbf{3}>\mathbf{4}>\mathbf{2}\right.$ ) (Table 3$)$. We propose that the bioactivity of $\mathbf{2}$ and $\mathbf{3}$ in the absence of S9-mix is due to their propensity to undergo facile one-electron reduction processes. It remains to be established if the enzymes responsible for the activation of nitro-PAH [56] are involved in this case. Notwithstanding, the search for other CP-PAH in the non-polar fraction of combustion exhausts with $E_{1 / 2}(0 /-1)$ in $\mathrm{V}$ versus SCE values in the range of the nitro-PAH is a timely issue.

\section{Conclusions}

The dicyclopenta-fused pyrenes 2-4 that have been identified as constituents of the non-polar fraction of combustion exhausts exhibit a positive, metabolism-dependent mutagenic response (TA98 + S9-mix). The marked dependence of the mutagenic response on the concentration of the S9-mix and especially the maximum mutagenic activity at low microsomal protein content (S9-mix 2\% (v/v)) indicate that the most plausible metabolic activation pathway for 2-4 is through a one-step epoxidation of the five-membered ring olefinic bonds. This is further corroborated by the lack of mutagenic activity of the partially hydrogenated derivatives $\mathbf{5 - 8}$, with and without S9-mix. The experimental results are supported by semi-empirical AM1 calculations. In line with the $\Delta H_{\mathrm{f}}^{\circ}$ stability order of $\mathbf{2 - 4}(\mathbf{3}>\mathbf{4}>\mathbf{2})$ and the $\Delta E$ values for the mono-epoxide (2a-4a), cis-di-epoxides $(\mathbf{2 b}-\mathbf{4 b})$ and trans-di-epoxides $(\mathbf{2 c}-\mathbf{4 c})$, the mutagenicity of 2-4 with S9-mix 2\% (v/v) follows the inverse order $(\mathbf{2}>\mathbf{4}>\mathbf{3})$, i.e. the less stable CP-PAH 2 appears to be the most reactive and bioactive.

Interestingly, CP-PAH 3 and to a lesser extent $\mathbf{2}$, which were identified as constituents in the non-polar fraction of combustion exhausts, were found to possess mutagenicity in the absence of S9-mix. It is proposed that the direct bioactivity of $\mathbf{3}$ involves one-electron reduction processes similar to those put forward to explain the direct mutagenic activity of nitro-PAH.

\section{Acknowledgements}

Financial support from the Gobierno Vasco, Beca para Formación de Investigadores (M.J. Otero Lobato) and technical support from Dr. A.Y. Simarro and S.M. Nijmeijer (Veterinary Pharmacology, Pharmacy and Toxicology, Utrecht University, The Netherlands) are gratefully acknowledged.

\section{Appendix A}

Mutagenic activity (determined as described in Section $2[25,26])$ of cyclopenta[cd]pyrene (1, Fig. 1) using the $S$. typhimurium strain TA98, without (-S9-mix) and with exogenous metabolic activation mixture $(+\mathrm{S} 9-\mathrm{mix} 2 \%(\mathrm{v} / \mathrm{v})$, i.e. $0.29 \mathrm{mg}$ protein per plate; standard $4 \%(\mathrm{v} / \mathrm{v})$, i.e. $0.58 \mathrm{mg}$ protein per plate; $10 \%(\mathrm{v} / \mathrm{v})$, i.e. $1.46 \mathrm{mg}$ protein per plate). The dose-response curves are compared in Fig. 6. 


\begin{tabular}{llccc}
\hline Concentration $(\mu \mathrm{g}$ per plate) & $-\mathrm{S} 9-\operatorname{mix}$ & $+\mathrm{S} 9-\operatorname{mix} 2 \%(\mathrm{v} / \mathrm{v})$ & $+\mathrm{S} 9-\operatorname{mix} 4 \%(\mathrm{v} / \mathrm{v})$ & $+\mathrm{S} 9-\operatorname{mix} 10 \%(\mathrm{v} / \mathrm{v})$ \\
\hline 0.0 & $15.5 \pm 6.5$ & $19 \pm 7.2$ & $22 \pm 5.5$ & $23 \pm 5.3$ \\
0.5 & $14 \pm 2$ & $64 \pm 11.5$ & $57.2 \pm 10.1$ & $51.3 \pm 21.8$ \\
1.0 & $18 \pm 0.8$ & $180.5 \pm 6.5$ & $116 \pm 31.6$ & $126 \pm 69.9$ \\
2.0 & $20.5 \pm 0.5$ & $616.5 \pm 10.2$ & $197.7 \pm 60.1$ & $455 \pm 363.5$ \\
4.0 & $50.5 \pm 7.5$ & $1113 \pm 80$ & $609.2 \pm 269.2$ & $819 \pm 583.9$ \\
8.0 & $48 \pm 17$ & $2247 \pm 450$ & $1356.8 \pm 161.8$ & $860 \pm 262.7$ \\
12.0 & $31 \pm 6$ & $2250 \pm 90$ & $1998.7 \pm 307.1$ & $1504 \pm 153.9$ \\
20.0 & $71 \pm 31.8$ & $2380 \pm 220$ & $2364 \pm 228$ & $2720 \pm 220$ \\
His revertants/nmol $\left(r^{2}\right)$ & $0.5(0.55)$ & $63.5(0.90)$ & $27.5(0.94)$ & $28.6(0.98)$
\end{tabular}

Results shown are mean values \pm standard deviation (from triplicate plates for each dose in two independent experiments), and are given in His revertants per plate, without correction for background.

Mutagenic activity (determined as described in Section $2[25,26])$ of dicyclopenta[cd,mn]pyrene (2, Fig. 1) using the S. typhimurium strain TA98, without $(-$ S9-mix $)$ and with exogenous metabolic activation mixture $(+\mathrm{S} 9-\operatorname{mix} 2 \%(\mathrm{v} / \mathrm{v})$, i.e. $0.29 \mathrm{mg}$ protein per plate; standard $4 \%(\mathrm{v} / \mathrm{v})$, i.e. $0.58 \mathrm{mg}$ protein per plate; $10 \%(\mathrm{v} / \mathrm{v})$, i.e. $1.46 \mathrm{mg}$ protein per plate). The dose-response curves are compared in Fig. 6.

\begin{tabular}{lcccc}
\hline Concentration $(\mu \mathrm{g}$ per plate) & $-\mathrm{S} 9$-mix & $+\mathrm{S} 9-\operatorname{mix} 2 \%(\mathrm{v} / \mathrm{v})$ & $+\mathrm{S} 9-\operatorname{mix} 4 \%(\mathrm{v} / \mathrm{v})$ & $+\mathrm{S} 9-\operatorname{mix} 10 \%(\mathrm{v} / \mathrm{v})$ \\
\hline 0.0 & $15.5 \pm 1.6$ & $19 \pm 6.5$ & $22 \pm 3.6$ & $23 \pm 5.3$ \\
0.25 & $17 \pm 3.3$ & $-^{\mathrm{a}}$ & $59.5 \pm 2$ & $58.3 \pm 8.4$ \\
0.5 & $19.7 \pm 6.1$ & $233 \pm 30.1$ & $184.5 \pm 1.5$ & $-^{\mathrm{a}}$ \\
1.0 & $38.3 \pm 7.8$ & $657 \pm 178.8$ & $415 \pm 65.1$ & $140 \pm 32.2$ \\
2.0 & $101 \pm 6$ & $1180 \pm 120$ & $745.2 \pm 107.4$ & $279.5 \pm 61.4$ \\
4.0 & $82 \pm 1.9$ & $2616 \pm 403.9$ & $2510 \pm 137.5$ & $760 \pm 95.5$ \\
8.0 & $129 \pm 19.6$ & $2340 \pm 224.9$ & $3258 \pm 698.0$ & $1970 \pm 270$ \\
12.0 & $-^{\mathrm{a}}$ & $1799 \pm 576$ & $-^{\mathrm{b}}$ & $1191 \pm 283$ \\
His revertants/nmol $\left(r^{2}\right)$ & $4.2(0.91)$ & $163.3(0.99)$ & $98.4(0.92)$ & $41.8(0.93)$
\end{tabular}

Results shown are mean values \pm standard deviation (from triplicate plates for each dose in two independent experiments), and are given in His revertants per plate, without correction for background.

${ }^{\text {a }}$ Dose not tested.

${ }^{\mathrm{b}}$ At $12 \mu \mathrm{g}$ per plate of $\mathbf{2}$ the number of His revertant colonies markedly increased hampering their precise manual counting. No toxicity is observed.

Mutagenic activity (determined as described in Section $2[25,26])$ of dicyclopenta[ $[c d, f g]$ pyrene $(3$, Fig. 1) using the S. typhimurium strain TA98, without $(-$ S9-mix) and with exogenous metabolic activation mixture $(+\mathrm{S} 9-\operatorname{mix} 2 \%(\mathrm{v} / \mathrm{v})$, i.e. $0.29 \mathrm{mg}$ protein per plate; standard $4 \%(\mathrm{v} / \mathrm{v})$, i.e. $0.58 \mathrm{mg}$ protein per plate; $10 \%(\mathrm{v} / \mathrm{v})$, i.e. $1.46 \mathrm{mg}$ protein per plate). The dose-response curves are compared in Fig. 6. 


\begin{tabular}{lcccc}
\hline Concentration $(\mu \mathrm{g}$ per plate) & $-\mathrm{S} 9-\mathrm{mix}$ & $+\mathrm{S} 9-\operatorname{mix} 2 \%(\mathrm{v} / \mathrm{v})$ & $+\mathrm{S} 9-\operatorname{mix} 4 \%(\mathrm{v} / \mathrm{v})$ & $+\mathrm{S} 9-\operatorname{mix} 10 \%(\mathrm{v} / \mathrm{v})$ \\
\hline 0.0 & $15.5 \pm 0.5$ & $19 \pm 6.5$ & $22 \pm 11.2$ & $23 \pm 6.4$ \\
0.5 & $42.3 \pm 3.9$ & $91 \pm 41.2$ & $55 \pm 4.1$ & $74 \pm 28.4$ \\
1.0 & $80 \pm 13$ & $213 \pm 132.1$ & $119.8 \pm 21.6$ & $135 \pm 58.8$ \\
2.0 & $130.6 \pm 30.2$ & $399 \pm 157.9$ & $162.5 \pm 18.9$ & $238 \pm 65.6$ \\
4.0 & $227.6 \pm 27.5$ & $823 \pm 316.8$ & $366 \pm 52.6$ & $442 \pm 226.6$ \\
8.0 & $399.8 \pm 64.8$ & $1585 \pm 207.1$ & $798.8 \pm 158.6$ & $1053 \pm 654.8$ \\
12.0 & $636.2 \pm 166$ & $1695 \pm 213.7$ & $1292.8 \pm 105.3$ & $1925 \pm 173.4$ \\
20.0 & $864 \pm 62.9$ & $652 \pm 80$ & $1854 \pm 175.9$ & $1280 \pm 180$ \\
His revertants/nmol $\left(r^{2}\right)$ & $11.7(0.98)$ & $48.0(0.99)$ & $23.2(0.98)$ & $38.5(0.98)$ \\
\hline
\end{tabular}

Results shown are mean values \pm standard deviation (from triplicate plates for each dose in two independent experiments), and are given in His revertants per plate, without correction for background.

Mutagenic activity (determined as described in Section $2[25,26])$ of dicyclopenta $[c d, j k]$ pyrene $(\mathbf{4}$, Fig. 1) using the S. typhimurium strain TA98, without (-S9-mix) and with exogenous metabolic activation mixture $(+\mathrm{S} 9$-mix $2 \%(\mathrm{v} / \mathrm{v})$, i.e. $0.29 \mathrm{mg}$ protein per plate; standard $4 \%(\mathrm{v} / \mathrm{v})$, i.e. $0.58 \mathrm{mg}$ protein per plate; $10 \%(\mathrm{v} / \mathrm{v})$, i.e. $1.46 \mathrm{mg}$ protein per plate). The dose-response curves are compared in Fig. 6.

\begin{tabular}{llccc}
\hline Concentration $(\mu \mathrm{g}$ per plate) & $-\mathrm{S} 9-\operatorname{mix}$ & $+\mathrm{S} 9-\operatorname{mix} 2 \%(\mathrm{v} / \mathrm{v})$ & $+\mathrm{S} 9-\operatorname{mix} 4 \%(\mathrm{v} / \mathrm{v})$ & $+\mathrm{S} 9-\operatorname{mix} 10 \%(\mathrm{v} / \mathrm{v})$ \\
\hline 0.0 & $15.5 \pm 10.6$ & $19 \pm 6.5$ & $22 \pm 9.6$ & $23 \pm 5.3$ \\
0.5 & $19.7 \pm 0.5$ & $217.5 \pm 152.5$ & $39.5 \pm 5.6$ & $94.5 \pm 35.6$ \\
1.0 & $30.1 \pm 8.9$ & $621.3 \pm 372.1$ & $63.6 \pm 10.7$ & $162.5 \pm 52.9$ \\
2.0 & $41.8 \pm 13.6$ & $1261.3 \pm 587.5$ & $125.5 \pm 46.5$ & $375.8 \pm 201.2$ \\
4.0 & $40.9 \pm 10.1$ & $1730 \pm 400.1$ & $218.1 \pm 43.7$ & $1034 \pm 538.9$ \\
8.0 & $64.4 \pm 9.1$ & $2325 \pm 398.8$ & $615.5 \pm 204.6$ & $-^{\mathrm{a}}$ \\
12.0 & $74.9 \pm 18.6$ & $2128 \pm 386.4$ & $1341 \pm 364.2$ & $1353 \pm 465.9$ \\
20.0 & $95.1 \pm 18.8$ & $1870 \pm 110$ & $2529 \pm 654.7$ & $1200 \pm 160$ \\
His revertants/nmol $\left(r^{2}\right)$ & $1.2(0.93)$ & $82.0(0.95)$ & $14.7(0.84)$ & $33.3(0.95)$
\end{tabular}

Results shown are mean values \pm standard deviation (from triplicate plates for each dose in two independent experiments), and are given in His revertants per plate, without correction for background.

${ }^{\text {a }}$ Dose not tested.

\section{References}

[1] U.E. Wiersum, L.W. Jenneskens, The formation of polyaromatic hydrocarbons, fullerenes and soot in combustion: pyrolytic mechanisms and the industrial and environmental connection, in: Y. Vallée (Ed.), Gas Phase Reactions in Organic Synthesis, Garden and Breach Science Publishers, New York, 1997, pp. 143-194.

[2] A.M. Mastral, M.S. Callen, T. García, Toxic organic emissions from coal combustion, Fuel Process. Technol. 67 (2000) 1-10.

[3] E. Eisenstadt, A. Gold, Cyclopenta $[c d]$ pyrene: a highly mutagenic PAH, Proc. Natl. Acad. Sci. U.S.A. 75 (1978) $1667-1669$.
[4] M.J. Kohan, R. Sangaiah, L.M. Ball, A. Gold, Bacterial mutagenicity of aceanthrylene: a novel CP-PAH of low molecular weight, Mutat. Res. 155 (1985) 95-98.

[5] A.L. Lafleur, J.P. Longwell, J.A. Marr, P.A. Monchamp, E.F. Plummer, W.G. Thilly, P.P.Y. Mulder, B.B. Boere, J. Cornelisse, J. Lugtenburg, Bacterial and human cell mutagenicity study of some $\mathrm{C}_{18} \mathrm{H}_{10}$ cyclopenta-fused PAH associated with fossil fuels combustion, Environ. Health Perspect. 101 (1993) 146-153.

[6] J.B. Howard, J.P. Longwell, J.A. Marr, C.J. Pope, W.F. Busby Jr., A.L. Lafleur, K. Taghizadeh, Effects of PAH isomerizations on mutagenicity of combustion products, Combust. Flame 101 (1995) 262-270. 
[7] W.F. Busby Jr., H. Smith, E.F. Plummer, A.L. Lafleur, P.P.Y. Mulder, B.B. Boere, J. Cornelisse, J. Lugtenburg, Mutagenicity of cyclopenta-fused polynuclear aromatic hydrocarbons and a non-polar fraction from a fuel combustion sample in a salmonella forward mutation assay without exogenous metabolic activation, Mutat. Res. 391 (1997) 117125 .

[8] A.L. Lafleur, J.P. Longwell, L. Shirname-More, P.A. Monchamp, W.A. Peters, E.F. Plummer, Chemical characterization and bacterial mutagenicity testing of ethylene combustion products from a jet-stirred/plug-flow reactor, Energy Fuels 4 (1990) 307-319.

[9] M. Sarobe, S. Flink, L.W. Jenneskens, B.L.A. van Poecke, J.W. Zwikker, Cyclopent $[f g]$ acepyrylene, cyclopent $[j k]$ acepyrylene and cyclopent $[m n]$ acepyrylene: novel $\mathrm{C}_{20} \mathrm{H}_{10}$ cyclopenta-fused PAH, J. Chem. Soc. Chem. Commun. (1995) 2415-2416.

[10] L.T. Scott, A. Necula, Synthesis and characterization of the three dicyclopentapyrenes, J. Org. Chem. 61 (1996) 386-388.

[11] A.L. Lafleur, J.B. Howard, E.F. Plummer, K. Taghizadeh, A. Necula, L.T. Scott, K.C. Swallow, Identification of some novel cyclopenta-fused PAH in ethylene flames, Polycycl. Aromat. Compd. 12 (1998) 223-237.

[12] E.B. Ledesma, M.A. Kalish, M.J. Wornat, P.F. Nelson, J.C. Mackie, Observation of cyclopenta-fused and ethynylsubstituted PAH during the fuel-rich combustion of primary tar from a bituminous coal, Energy Fuels 13 (1999) 11671172.

[13] H. Richter, V. Risoul, A.L. Lafleur, E.F. Plummer, J.B. Howard, W.A. Peters, Chemical characterization and bioactivity of PAH from non-oxidative thermal treatment of pyrene-contaminated soil at $1000^{\circ} \mathrm{C}$, Environ. Health Perspect. 108 (2000) 709-717.

[14] C.J. Pope, W.A. Peters, J.B. Howard, Thermodynamic driving forces for PAH isomerization and growth during thermal treatment of polluted soils, J. Hazard. Mater. 79 (2000) 189208.

[15] H.H. Saito, V. Bucalá, J.B. Howard, W.A. Peters, Thermal removal of pyrene contamination from soil: basic studies and environmental health implications, Environ. Health Perspect. 106 (1998) 1097-1107.

[16] A. Gold, S. Nesnow, M. Moore, H. Garland, G. Curtis, B. Howard, D. Graham, E. Eisenstadt, Mutagenesis and morphological transformation of mammalian cells by a non-bay-region polycyclic cyclopenta $[c d]$ pyrene and its 3,4-oxide, Cancer Res. 40 (1980) 4482-4484.

[17] A.W. Wood, W. Levin, R.L. Chang, M. Huang, D. Ryan, P.E. Thomas, R. Lehr, S. Kumar, M. Koreeda, H. Akagi, Y. Ittah, P. Dansette, H. Yagi, D.M. Jerina, A.H. Conney, Mutagenicity and tumor-initiating activity of cyclopenta $[c d]$ pyrene and structurally related compounds, Cancer Res. 40 (1980) 642649.

[18] E. Cavalieri, E. Rogan, B. Toth, A. Munhall, Carcinogenicity of the environmental pollutants cyclopenteno $[c d]$ pyrene and cyclopentano $[c d]$ pyrene in mouse skin, Carcinogenesis 2 (1981) 227-281.
[19] A. Gold, E. Eisenstadt, Metabolic activation of cyclopenta[cd]pyrene to 3,4-epoxycyclopenta[cd]pyrene by rat liver microsomes, Cancer Res. 40 (1980) 3940-3944.

[20] P.P. Fu, F.A. Beland, S.K. Yang, CP-PAH: potential carcinogens and mutagens, Carcinogenesis 1 (1980) 725-727.

[21] S.M. Fetzer, C.-R. Huang, R.G. Harvey, P.R. LeBreton, Photoelectron and ab initio molecular orbital investigations of genotoxic benz $[a]$ anthracene metabolites: electronic influences on DNA binding, J. Phys. Chem. 97 (1993) 23852394.

[22] A.C. Beach, R.C. Gupta, DNA adducts of the ubiquitous environmental contaminant cyclopenta $[c d]$ pyrene, Carcinogenesis 15 (1994) 1065-1072.

[23] W.T. Hsu, P.L. Skipper, S.R. Tannenbaum, DNA adduct formation by secondary metabolites of cyclopenta[ $[c d]$ pyrene in vitro, Cancer Lett. 136 (1999) 137-141.

[24] Y.-J. Surh, H. Kwon, S.R. Tannenbaum, Sulfotransferasemediated activation of 4-hydroxy- and 3,4-dihydroxy-3,4dihydrocyclopenta $[c d]$ pyrene, major metabolites of cyclopenta $[c d]$ pyrene, Cancer Res. 53 (1993) 1017-1022.

[25] B.N. Ames, J. McCann, E. Yamasaki, Methods for detecting carcinogens and mutagens with the salmonella/ mammalian-microsome mutagenicity test, Mutat. Res. 31 (1975) 347-364.

[26] D.M. Maron, B.N. Ames, Revised methods for the salmonella mutagenicity test, Mutat. Res. 113 (1983) 173-215.

[27] K. Mortelmans, E. Zeiger, The Ames salmonella/microsome mutagenicity assay, Mutat. Res. 455 (2000) 29-60.

[28] O.H. Lowry, N.J. Rosebrough, A.L. Farr, R.J. Randall, Protein measurement with the folin phenol reagent, J. Biol. Chem. 193 (1951) 265-275.

[29] H.M. Wortelboer, C.A. de Kruif, A.A.J. van Iersel, H.E. Falke, J. Noordhoek, B.J. Blaauboer, The isoenzyme pattern of cytochrome $\mathrm{P} 450$ in rat hepatocytes in primary culture comparing different enzyme activities in microsomal incubations and intact monolayers, Biochem. Pharm. 40 (1990) 2525-2534.

[30] R. Mermelstein, D.K. Kiriazides, M. Butler, E.C. McCoy, H.S. Rosenkranz, The extraordinary mutagenicity of nitropyrenes in bacteria, Mutat. Res. 89 (1981) 187-196.

[31] L.M. Ball, S.H. Warren, R. Sangaiah, A. Gold, Bacterial mutagenicity of two cyclopentafused isomers of benzpyrene, Mutat. Res. 260 (1991) 271-279.

[32] B.S. Kim, B.H. Margolin, Statistical methods for the Ames salmonella assay: a review, Mutat. Res. 436 (1999) 113-122.

[33] L. Claxton, J. Allen, A. Auletta, K. Mortelmans, E. Nestmann, E. Zeiger, Guide for the Salmonella typhimurium/mammalian microsome tests for bacterial mutagenicity, Mutat. Res. 189 (1987) 83-91.

[34] N.F. Cariello, W.W. Piegorsh, The Ames test: the two-fold rule revisited, Mutat. Res. 133 (1996) 23-31.

[35] M.J.S. Dewar, E.G. Zoebisch, E.F. Healy, J.J.P. Stewart, AM1: a new general purpose quantum mechanical molecular model, J. Am. Chem. Soc. 107 (1985) 3902-3909.

[36] S. Nesnow, S. Leavitt, R. Easterling, R. Watts, S.H. Toney, L. Claxton, R. Sangaiah, S.H. Toney, J. Wiley, P. Fraher, A. Gold, Mutagenicity of cyclopenta-fused isomers 
of benz $[a]$ anthracene in bacterial and rodent cells and identification of the major rat liver microsomal metabolites, Cancer Res. 44 (1984) 4993-5003.

[37] D.M. Jerina, R. Lehr, M. Schaefer-Ridder, H. Yagi, J.M. Karle, D.R. Thakker, A.W. Wood, A.Y.H. Lu, D. Ryan, S. West, W. Levin, A.H. Conney, Bay-region epoxides of dihydrodiols: a concept explaining the mutagenic and carcinogenic activity of benzo[ $[a]$ pyrene and benzo $[a]-$ anthracene, Cold Spring Harbor Conf. Cell Proliferation 4 (1977) 639-658.

[38] R.W.A. Havenith, H. Jiao, L.W. Jenneskens, J.H. van Lenthe, P.V.R. Schleyer, M. Kataoka, A. Necula, L.T. Scott, Stability and aromaticity of the cyclopenta-fused pyrene congeners, J. Am. Chem. Soc. 124 (2002) 2363-2370.

[39] E. Steiner, P.W. Fowler, Patterns of ring currents in conjugated molecules: a few electron model based on orbital contributions, J. Phys. Chem. A 105 (2001) 9553-9562.

[40] P.W. Fowler, E. Steiner, A. Acocella, L.W. Jenneskens, R.W.A. Havenith, Mapping the modification of ring currents induced by cyclopenta fusion on a naphthalene core, J. Chem. Soc., Perkin Trans. 2 (7) (2001) 1058-1065.

[41] E. Steiner, P.W. Fowler, L.W. Jenneskens, R.W.A. Havenith, Local and global paratropic and diatropic ring currents in pyrene and its cyclopenta-fused congeners, Eur. J. Org. Chem. (2002) 163-169.

[42] B. Freiermuth, S. Gerber, A. Riesen, J. Wirz, M. Zehnder, Molecular and electronic structure of pyracylene, J. Am. Chem. Soc. 112 (1990) 738-744.

[43] M. Lutz, A.L. Spek, M. Sarobe, L.W. Jenneskens, Acefluoranthylene, Acta Cryst. 55 (1999) 659-661.

[44] D.M. Jerina, R.E. Lehr, H. Yagi, O. Hernandez, P.M. Dansette, P.G. Wislocki, A.W. Wood, R.L. Chang, W. Levin, A.H. Conney, Mutagenicity of $\mathrm{B}[a] \mathrm{P}$ derivatives and the description of a quantum mechanical model which predicts the use of carbonium ion formation from diol-epoxides, in: F.J. deSerres, J.R. Fouts, J.R. Bend, R.M. Philpot (Eds.), In Vitro Metabolic Activation in Mutagenesis Testing, Elsevier/North Holland, Biomedical Press, Amsterdam, 1976, pp. 159-177.

[45] L.M. Ball, S.H. Warren, R. Sangaiah, S. Nesnow, A. Gold, Bacterial mutagenicity of new cyclopenta-fused cata- annelated PAH, and identification of the major metabolites of benz[j]acephenanthrylene formed by aroclor-treated rat liver microsomes, Mutat. Res. 224 (1989) 115-125.

[46] P.P. Fu, D. Herrero-Saenz, Nitro-PAH: a class of genotoxic environmental pollutants, Environ. Carcin. Ecotoxicol. Rev. C17 (1999) 1-43.

[47] L.M. Ball, M.J. Kohan, L.D. Claxton, J. Lewtas, Mutagenicity of derivatives and metabolites of 1-nitropyrene: activation by rat liver S9 and bacterial enzymes, Mutat. Res. 138 (1984) 113-125.

[48] S. Ning, X. Xiaobai, Reductive metabolism of 4-nitrobiphenyl by rat liver fraction, Carcinogenesis 18 (1997) 1233-1240.

[49] H. Jung, A.U. Shaikh, R.H. Heflich, P.P. Fu, Nitro group orientation, reduction potential, and direct-acting mutagenicity of nitro-PAH, Environ. Mol. Mutat. 17 (1991) 169-180.

[50] J.E. Combariza, A.K.D. Hajos, G.W. Winston, Semiempirical calculations of nitrated pyrenes and their reduced metabolites: relationship to characteristics of bioactivation, J. Phys. Chem. 99 (1995) 14539-14543.

[51] A.T. Maynard, L.G. Pedersen, H.S. Posner, J.D. McKinney, An ab initio study of the relationship between nitroarene mutagenicity and electron affinity, Mol. Pharmacol. 29 (1986) 629-636.

[52] G. Klopman, D.A. Tonucci, M. Holloway, H.S. Rosenkranz, Relationship between polarographic reduction potential and mutagenicity of nitroarenes, Mutat. Res. 126 (1984) 139-144.

[53] C. Koper, L.W. Jenneskens, M. Sarobe, Externally-fused cyclopenta-moieties in non-alternant CP-PAH act as Peri-substituents, Tetrahedron Lett. 43 (2002) 3833-3836.

[54] C. Koper, Non-alternant polycyclic aromatic hydrocarbons versus closed carbon surfaces, Ph.D. Thesis, Debye Institute, Utrecht University, Utrecht, The Netherlands, 2003, p. 216.

[55] C. Koper, M. Sarobe, L.W. Jenneskens, Redox properties of non-alternant CP-PAH: the effect of peripheral pentagon annelation, Phys. Chem. Chem. Phys. 6 (2004) 319-327.

[56] V. Purohit, A.K. Basu, Mutagenicity of nitroaromatic compounds, Chem. Res. Toxicol. 13 (2000) 673-691.

[57] T. Koopmans, The distribution of wave function and characteristic value among the individual electrons of an atom, Physica 1 (1933) 104-113. 